\title{
A proposal for a new system of classification for hotels based on information taken from a multi- sponsor loyalty program
}

\section{Propuesta de clasificación de la oferta hotelera a partir de la información de un programa de fidelización multi-esponsor}

\author{
Josefa D. Martin-SAntana ${ }^{1}$ \\ Eva ReINARES-LaRA ${ }^{2}$ \\ Pedro Reinares-Lara ${ }^{2}$ \\ Universidad de Las Palmas de Gran Canaria (España) \\ Universidad Rey Juan Carlos (España)
}

Recibido el 8 de abril de 2015, aceptado el 14 de septiembre de 2015

Publicado online el 4 de mayo de 2016

$\mathrm{N}^{\mathrm{o}}$ de clasificación JEL: M31

DOI: $10.5295 / \mathrm{cdg} .150535 \mathrm{er}$

\begin{abstract}
:
This work aims to provide an innovative classification of hotels based on guests' assessments of the attributes that influence the choice of a particular hotel. To this end, information provided by a multi-sponsor loyalty program will be used due to the large number of hotel chains associated with these kinds of programs and their ability to collect and process information from their users more effectively than conventional research procedures. In this paper, we have conducted an exploratory qualitative study using six focus groups each with a sample of 60 people and a self-administered questionnaire applied to a sample of 73,698 users of a loyalty program who have redeemed points at a hotel. This proposal for a new system of classification highlights the disparity between supply and demand in the way hospitality services are promoted in the Spanish market, as well as hotel classification to be optimised according to those features that really make an offer stand out from the perspective of the customer. This contribution will allow types of establishment in each of the new categories proposed in this paper to be precisely matched to customer profiles. In addition to providing an instrument through which the client can identify establishments more in line with their preferences.
\end{abstract}

Keywords:

Hospitality services, hotel classification, tourism marketing, loyalty programs.

\footnotetext{
1 Facultad de Economía, Empresa y Turismo. Department of Business Administration. Edificio Empresariales. Módulo C. Campus de Tafira. 35017. Islas Canarias (Spain). josefa.martin@ulpgc.es

2 Facultad de Ciencias Jurídicas y Sociales. Department of Business Administration. Paseo de los Artilleros s/n. Campus de Vicalvaro. 28032. Madrid (Spain).eva.reinares@urjc.es; pedro.reinares@urjc.es
} 
A proposal for a new system of classification for hotels based on information taken from a multi-sponsor loyalty program

\section{Resumen:}

El objetivo de este trabajo es aportar una clasificación innovadora de los establecimientos hoteleros basada en la valoración de sus usuarios de los atributos que fundamentan la elección de un hotel. Para ello se va utilizar la información que proporciona un programa de fidelización multi-esponsor, debido al gran número de cadenas hoteleras que se asocian a este tipo programas y a su capacidad para obtener y tratar la información de sus usuarios de una forma más eficaz en comparación con procedimientos convencionales de investigación. En este trabajo se ha aplicado un estudio exploratorio de carácter cualitativo mediante seis focus groups con una muestra de 60 personas, y una encuesta personal aplicada a una muestra de 73.698 usuarios de un programa de fidelización que han redimido sus puntos en un establecimiento hotelero. La propuesta de clasificación proporcionada evidencia el desajuste entre la oferta y la demanda en el mercado español en la forma de comercializar los servicios hoteleros, y permite optimizar el posicionamiento y la comunicación de los mismos a partir de los atributos que realmente diferencian la oferta desde la perspectiva del cliente. Esta contribución permitirá relacionar las nuevas tipologías de establecimientos propuestas con los perfiles de consumidores afines a cada una de las categorías de hoteles. De la misma manera puede ser un instrumento eficaz mediante el que el cliente identificará los establecimientos más acordes con sus preferencias.

\section{Palabras clave:}

Servicios hoteleros, cclasificación hotelera, marketing turístico, programas de fidelización. 


\section{INTRODUCTION}

The limitations of current systems of administrative classification for hotel services and their limited capacity for establish communication strategies and market positioning have been argued in both business and academic circles (De Querol 2010). Furthermore, marketing strategies carried out by hotels are undermining the ability of price to communicate to customers a certain level of service and quality. Hence, the role of price as the principal indicator of the quality of a hotel and the services they offer may be conditioned by the quality and extent of the information primarily communicated by hotels through the Internet - to which must be added new procedures for seasonal adjustment related to demand (yield management) - which is causing a noticeable homogenization of this variable (Marmorstein et al. 2003).

In such a highly competitive environment as the Spanish tourism market, hotels need to be able to specialize in order to attract specific customer and avoid having to compete in highly saturated and indistinct markets characterized by aggressive promotions (Aguiló and Alegre 2004). The benefits of being oriented towards the needs of specific target groups in shaping hotel services are undeniable, and allow the evolution of a product to be geared towards a market defined by demand and competition. The challenge requires adapting the design of the hotel service to new diverse groups of customers who are becoming ever more refined and experienced, and who make use of multiple sources of information online in their process of decision-making while making purchases or researching the features they desire of an establishment. In many cases, these features differ markedly from those taken into consideration by hotels in their own promotions. The existence of differences in the assessments made by customers about hotels' facilities or services, as well as their levels of satisfaction (Callan and Kyndt 2001; Varela et al. 2006; Füller and Matzler 2008), suggests that there is no homogeneity among customers, either in terms of the type of features which are considered and assessed, or as to the impact of these to generate greater customer satisfaction. In the review of the literature on the variables of segmentation for the tourism market, the works of Park and Yoon (2009) and Devesa et al. (2010) highlight the motivation of the customer as an important variable of segmentation, while Marques et al. (2010) emphasize the benefits sought. Hence, orientation towards specific segments requires hotel managers to know precisely the features that customers take into consideration when looking for establishments that meet their requirements and expectations. In this way, managers can develop and communicate a position that stands out among the less well-defined alternatives on offer. By getting to know their direct competition in the environment in which they operate, they can endeavour to provide unique value, not only in order to tilt customer choice towards their own establishments (Carrillero et al. 2012), but also to enhance customer relationships through loyalty programs that create a close link between the hotel and the guest (Lara and Martinez 2002).

From this perspective, different studies have addressed the potential of multi-sponsor loyalty programs as a means of making the marketing of tourism services more dynamic (Dekay et al. 2009). In fact, a loyalty program designed correctly can become, from a strategic point of view, a valuable tool for the proper management of the differences that exist among consumers in mass markets (Mauri 2003; Ziliani and Bellini 2004). Along this line, Reinares et al. (2010) indicate that the information provided by loyalty programs is a 
viable resource for the effective management of mass markets through segmentation. Other authors, such as Meyer-Waarden and Benavent (2003), argue that the potential of loyalty programs should be assessed for their ability to engender personalised, tailor-made marketing campaigns. Among its benefits, Kopalle and Neslin (2003) and Ziliani and Bellini (2004) recognize the contribution of these programs to the improvement of IT systems that gather information on customers by monitoring the transactions carried out with the company in particular and through commercial research applied to the management of client diversity (Byrom 2001; Cortiñas et al. 2005). To sum up, these uses come from the ability of these programs to collect and process information more effectively when compared to conventional methods of investigation (Rowley 2005).

The incentives and benefits - or rewards - received for participation in loyalty programs represent a great potential resource for providing information about customers. Hotel services are some of the rewards most frequently requested by guests affiliated with such programs (Ponzoa and Reinares 2010). Therefore, hotels associated with a multi-sponsor platform obtain, in addition to the many advantages bestowed on a company using this marketing tool, the use of the program as an alternative channel for distribution and communication among the millions of people associated with these programs (Ponzoa and Reinares 2010).

In this context, and based on the analysis of information provided by loyalty programs, the primary objective of this study is to provide an innovative system of classification for accommodation based on the motivations of customers that underlie hotel selection.

To this end, first the qualities of loyalty programs in the context of businesses providing hotel services will be presented, followed by a reflection on the limitations of the current, government system for the classification of hotels. In empirical research, customer information from a multi-sponsor loyalty program has been combined with data provided by an ad hoc survey.

The main contribution of this work is the proposal for a new system of hotel classification which could be part of a strategy for the differentiation of establishments. This system of classification is proposed as a means to optimize hotels' market positioning and communication, in addition to providing an instrument through which the client can identify establishments more in line with their preferences. This contribution will allow types of establishment in each of the new categories proposed in this paper to be precisely matched to customer profiles.

\section{MULTI-SPONSOR LOYALTY PROGRAMS AND HOTEL SERVICES}

Multi-sponsor programs are developed through agreements among leading companies from different comercial sectors with the aim of providing the user with a wide range of possibilities to accumulate points, while at the same time sharing the cost of administration and rewards. Their greatest value is in the quality of information provided by complementary businesses participating in these programs and the possibility to pass clients among affiliated companies (Long and Schiffman 2000). Specifically, the qualities of loyalty programs to satisfy the objective behind this work is derived from the high penetration of multi-sponsor programs into the population (millions of members), the socio-demographic 
profile of their members, and the high number of points redeemed on loyalty programs within the tourism industry, especially on hotel services (Kim et al. 2001). Moreover, according to a study by Hosteltur and Deloitte (2012), 30\% of travel agencies considered loyalty programs relevant in the selection of a holiday package.

It is important for hotel service companies to know how to appropriately manage the potential of loyalty programs, as much for the high number of companies that offer this marketing tool (either directly or through a multi-sponsor format), as for the relative importance that hotels have within the range of rewards offered by programs to their members (Michels and Bowen 2004). In fact, in the program on which the empirical analysis of this research was conducted, about $63 \%$ of the points earned by guests were exchanged for travel services. This conversion means that $30.9 \%$ of the rewards reported by loyalty programs fall into the category of tourist services. For the hotel industry it is significant that $16.5 \%$ of participants chose hotel accomodation as a reward, using $20.4 \%$ of the points generated by the program (see Table 1).

Table 1

Percentage of points exchanged for hotel accomodation vs. other categories of reward in a loyalty program (2014)

\begin{tabular}{|c|c|c|c|}
\hline Type of Reward & Users & Rewards & Points \\
\hline Hotels & $16.5 \%$ & $16.6 \%$ & $20.4 \%$ \\
\hline Combined services & $8.2 \%$ & $4.0 \%$ & $23.1 \%$ \\
\hline Airline tikets & $15.1 \%$ & $10.3 \%$ & $19.8 \%$ \\
\hline Total exchanges for tourist services & $39.9 \%$ & $30.9 \%$ & $63.4 \%$ \\
\hline Tangible rewards & $42.1 \%$ & $42.2 \%$ & $19.4 \%$ \\
\hline Charity donations & $0.4 \%$ & $0.2 \%$ & $1.1 \%$ \\
\hline Discount coupons & $1.1 \%$ & $1.2 \%$ & $0.6 \%$ \\
\hline Leisure and Experiences & $16.6 \%$ & $25.6 \%$ & $15.5 \%$ \\
\hline Total exchanges for rewards not related to tourism & $60.1 \%$ & $69.1 \%$ & $36.6 \%$ \\
\hline TOTAL & $100 \%$ & $100 \%$ & $100 \%$ \\
\hline
\end{tabular}

Source: Own elaboration based on data from the TURYOCIO loyalty program.

In this context, multi-sponsor loyalty programs can be an instrument that provides effective solutions for marketing activities in the hotel sector (Dekay et al. 2009). However, Dekay et al. (2009) argue that not all types of tourist services have adequately developed these programs, so the management of the benefits they bring varies noticeably among different types of businesses. Specifically, the shortcomings in the management of loyalty programs promoted by the hotel industry are highlighted since the benefits are not sufficiently exploited by all associated establishments. 


\section{THE IMPORTANCE OF A SYSTEM OF HOTEL CLASSIFICATION BASED ON DEMAND}

The management of hotel categories is a key strategic variable that directly influences a hotel's performance (Claver et al. 2007). The idea of classifying service sectors in order to achieve a more strategic perspective on marketing decisions is not new. Lovelock (1983) recognizes that services comprise a complex and varied set of activities and that their classification according to type may be limited, given that it implies an orientation towards sales that complicates the planning of marketing strategies under the principles of consumer orientation. In this sense, it has been argued that the classification of services based on the key features in demand would allow them to be categorized in terms of the real needs of consumers likely to be dealt with by marketing actions (Palmer et al. 2000).

Administrative classification according to the category of the establishment is the most important requirement for hotels. It is made based on the presence of certain services offered, as well as certain technical requirements and equipment. In Spain, the category is represented by a number of stars. Tourism industry jargon has been simplified by grouping the various hotel classifications into five categories: luxury, semi-luxury, premiere superior, premiere, and standard (Albert 1999). In addition to classification by category, there exists a diverse set of criteria which could give rise to additional classifications. For example, it is possible to request that the government recognize some kind of specialization according to various criteria or the services offered (e.g., Q for Quality). However, various sources argue that the current system of hotel classification, regulated by the government, is insufficient in describing the diversity of the hotels on offer and providing the customer with the information they need to make an informed decision (Reinares and Esteban 1996; Guillet and Law 2010). Moreover, according to Caso and Iglesias (2013), despite the benefits that come with a certification of quality, from a business perspective there is no consensus on its influence over the performance of establishments, since there is a clear demonstration of bias towards the high-price segment. Furthermore, the national character of the most common certifications may be an obstacle to their spread among the hotel chains oriented towards international tourism (Caso Fernández-Pacheco 2012).

According to Campo and Yague (2011, p. 827) "it is possible that the systems of classification that purport to be objective indications of the quality of the services offered may differ from the perception of the guest." These authors go on to claim that "the category of the hotel is an indicator of price, but is not necessarily an indicator of the level of quality", since the categories indicated are not reviewed regularly once assigned "and may give mixed signals to customers when hotels with the same star rating but with varying degrees of quality in terms of the services offered are present in the market." It is therefore possible that the current system of classification does not provide an objective indication of the quality of services offered by the hotel and, therefore, cannot influence hotel selection (López and Serrano 2004). Moreover, Reinares and Esteban (1996) identify a problem arising from the partial information that emerges from the existence of hotel categories based on prior official classification. These authors verify that demand often establishes an idealised image of the hotel based on features or services that may not actually be present in all categories. 
Regarding the price of the hotel, as indicated Campo and Yague (2011, p. 827), the high level of competition among hotels has forced most of them, especially in the superior categories, to reduce their average prices, resulting in a narrowing of the price differential among categories. Moreover, the penetration of the Internet as a channel for communication and marketing has had a great influence on the homogenization of local prices due to the ease with which offers may be compared. This, coupled with the large volume of information available online regarding hotels, may favour the consumer in guiding their decision according to specific features and independently of price (Noone and McGuire 2013).

Therefore, neither the price nor the administrative categorization of the hotels are features that can be used exclusively in this context to inform potential customers about the ability of the hotel to satisfy, in a uniquely specialised way, the motivations that lie behind demand (Sanchez-Ollero et al. 2014). For hotel managers, having a classification for their establishments that serves as an outward sign of the distinguishing features and the particular services they provide, in comparison to their direct competitors, is a priority in an environment where, more than ever, orientation towards the customer is needed (Lo et al. 2010).

It is obvious that hotels' marketing strategies will be more effective if classifications that integrate the criteria that customers have when selecting a particular hotel are made full use of, and that, in turn - according to the approach of Montoro et al. (2006) - will enable them to differentiate among the various types of establishment on offer. In the context of market orientation in the hotel industry, it is necessary to check whether consumers are able to differentiate, according to their own criteria, among hotels, and if - according to this information - it is possible to develop a classification that matches the features actually considered important by guests.

From the operational point of view, this goal involves numerous methodological difficulties. It is complex to develop research to collect data representative of a large sample of consumers who can collectively assess all offers made by hotels. However, in the context of a loyalty program, the information available in a multi-sponsor database regarding hotels and their guests makes it feasible to propose, as an objective, the provision of a representative system of classification for hotels based on the criteria and perceptions of users (Allaway et al. 2006). This proposed system of classification will allow the potential mismatch between supply and demand in the Spanish hotel services market to be highlighted. The objective of transferring classifications to a positioning map in order to facilitate the understanding of this information on the part of the hotel managers also arises, which is an essential procedure for helping marketing managers in strategic decision making (Mazanec 1995).

\section{RESEARCH DESIGN}

The research was conducted in two sequential phases, qualitative and quantitative, as reflected schematically in Figure 1. 
Figure 1

\section{Research Design}

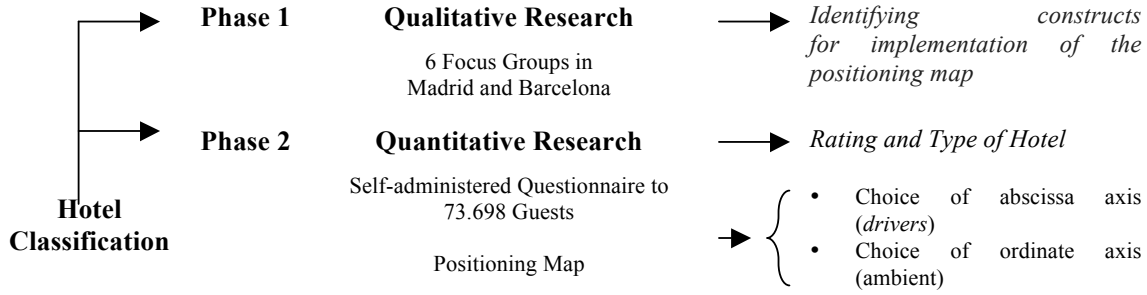

Source: Own elaboration.

In the first phase, with the primary aim of determining the motivations associated with choosing a hotel, six focus groups took place in Madrid and Barcelona, each with a sample of 60 aged $18+$ years and sociodemographically similar of the Spanish population. Three focus groups were conducted with users of loyalty programs and three with non-users. The aim was to test whether guests are capable of considering generic elements versus specific aspects (Hair et al. 2007). Prior to this, a wide range of features had been selected which, according to various authors (Reinares and Esteban 1996; Yavas and Babakus 2003; Ibrahim and Gill 2005; Kandampully and Suhartanto 2013), are relevant to the process of hotel selection. These were introduced in order to stimulate group dynamics (see Figure 2).

Figure 2

\begin{tabular}{l} 
Generic Stimuli \\
$\begin{array}{l}\text { Themes introduced regarding hotels } \\
\text { Perception of hotels } \\
\text { Motivations in the selection of a hotel }\end{array}$ \\
\hline $\begin{array}{ll}\text { Settings with places of interest } & \\
\text { Settings with nature tours } & \text { Security of establishment } \\
\text { Settings with interesting archaeological sites } & \text { Quality of food } \\
\text { Opttings with monuments } & \text { Opportunity to try international cuisine } \\
\text { Settings with a variety of historical and cultural visits } & \text { Excellent service } \\
\text { Settings with a variety of events and festivals } & \text { Relaxing atmosphere } \\
\text { Settings with beautiful parks and gardens } & \text { Satisfaction of expectations } \\
\text { Settings with good shopping facilities } & \text { Value for money } \\
\text { Aqua parks } & \text { High level of cleanliness and hygeine } \\
\text { Beautiful beaches } & \text { Good room facilities (bar, TV, wifi, safe, etc.) } \\
\text { Interesting nightlife } & \text { Provision of external services (pool, spa, tennis } \\
\text { Good climate/weather } & \text { courts, etc.) } \\
\text { Efficient modes of transport } & \text { Provision of complementary services (function } \\
\text { Cultural empathy with the environment } & \text { room, access to a translator, etc.) } \\
\text { Opportunity to participate in adventure activities } & \text { Personalized service } \\
\text { Opportunity to participate in outdoor activities } & \text { Professionalism of staff } \\
\text { Opportunity to participate in family activities } & \text { Speed of service } \\
\text { Security of location } & \text { Staff friendliness } \\
\text { Situated in desired location } & \text { General atmosphere }\end{array}$ \\
\hline
\end{tabular}

Source: Own elaboration based on Reinares and Esteban (1996); Yavas and Babakus (2003); Ibrahim and Gill (2005); Kandampully and Suhartanto (2013). 
To process the qualitative data, the qualitative analysis software ATLAS/ti ${ }^{3}$ Version 6.0 was used, which allows the organization and restructuring of the data for the interrelation of codes, concepts and categories of information which lead to conceptual networks (Murh 2004). By axial coding, different nodes emerged in the group dynamics related to two categories/constructs: (a) Style (conservative - modern), which includes features related to the the hotel decor and facilities; and (b) Drivers (internal facilities - external facilities), in which the hotel's onsite performance is compared against the environment in which the hotel is located - for example, near a golf course or a beach - in order to determine which is more relevant as a factor in selection.

The quantitative research was based on the database of one of the most important multi-sponsor loyalty programs in the Spanish market in terms of the number of participating companies and transaction volume. The loyalty program used is distributed over the entire Spanish territory and has been on operation for twenty years, and currently has approximately 1.5 million active users. Given the high penetration of multi-sponsor programs in Spanish society, the sociodemographic structure of its membership is representative of the main strata of the population (Reinares et al. 2010). The sample is conformed by members of the program who had made at least one transaction in at least one of the hotels associated with the program in the period between June 2010 and June 2011. In total, the self-administered questionnaire was given to 73,698 guests who assessed hotels across all administrative categories. The program includes 2,970 associated hotels. Table 2 shows the profile of the sample respondents. This information was obtained from the database of the loyalty program.

Table 2

\section{Sample distribution}

\begin{tabular}{|c|c|c|c|c|c|}
\hline Characteristics & $\mathbf{N}$ & $\%$ & Characteristics & $\mathbf{N}$ & $\%$ \\
\hline Gender & & & Number of years in program & & \\
\hline Male & 47,205 & 64.1 & Less than 3 years & 19,826 & 28.0 \\
\hline Female & 26,130 & 35.5 & 4 years & 9,797 & 14.0 \\
\hline Socioeconomic status & & & $5-6$ years & 21,900 & 31.0 \\
\hline Modest & 10,541 & 14.0 & 7 years & 6,748 & 9.0 \\
\hline Average & 38,207 & 52.0 & 8 years or more & 13,044 & 18.0 \\
\hline High & 9,064 & 12.0 & Number of points consumed & & \\
\hline Elite & 9,986 & 14.0 & Fewer than 9,000 & 14,883 & 21.0 \\
\hline Composition of household & & & $9,000-17,000$ & 14,553 & 20.0 \\
\hline 1 person & 14,646 & 21.1 & $17,001-28,000$ & 13,889 & 19.0 \\
\hline 2 people & 10,964 & 15.5 & $28,001-50,000$ & 14,178 & 20.0 \\
\hline 3 people & 12,278 & 17.2 & More than 50,000 & 13,812 & 19.0 \\
\hline 4 people & 20,773 & 28.7 & $\begin{array}{l}\text { Age at the moment of } \\
\text { exchange }\end{array}$ & & \\
\hline 5 people & 8,597 & 11.9 & Under 34 years & 15,645 & 23.3 \\
\hline More than 5 people & 4,075 & 5.7 & $34-40$ & 11,639 & 17.3 \\
\hline Residence & & & $41-48$ & 14,390 & 21.4 \\
\hline Capital & 33,924 & 48.0 & $49-55$ & 12,793 & 19.0 \\
\hline Province & 37,391 & 52.0 & Over 55 years & 12,742 & 19.0 \\
\hline
\end{tabular}

Source: Own elaboration.

\footnotetext{
3 The Atlas software, for the qualitative treatment of elevated textual information, can process complex information in an intuitive way using graphical representations of the various components and the relationships established between them.
} 
From the results of the qualitative analysis, a short questionnaire with semantic differential scales of 10 points was applied to individually assess different hotels regarding the motivations identified in the qualitative study. They were reduced to the two constructs proposed. The questionnaire was applied at the time the person named on the loyalty program cancelled their account with a hotel. Through the identification code of the program, survey data is automatically cross-referenced with the data in the loyalty program database (hotel, demographic profile, transactional behaviour in the program). The questionnaire included two questions (with explanatory information about the items of the questions): (1) Indicate the main reason why you have chosen this hotel, with 1 being the most important in terms of provisions and amenities and 10 being the most important in terms of aspects relating to the location of the hotel; and, (2) Rate whether you consider this hotel and its facilities 'Classic' or 'Modern', with 1 being that you consider the hotel as 'Classic' and 10 being the maximum rating of the hotel as 'Modern '

\section{RESULTS: PROPOSAL FOR SYSTEM OF CLASSIFICATION FOR HOTELS}

As already indicated above, qualitative research has identified two main criteria (constructs) that stood out in terms of importance as preferred factors in hotel selection. The results obtained from the quantitative study, in which respondents rated the hotel based on the two bipolar constructs above, have been plotted onto a positioning map whose axes are the two constructs and on which is shown the individual assessments of 73,698 guests at different hotels (Figure 3). Each one of the 73,698 assessments is projected as a point in one of four quadrants formed by the constructs Style-Drivers. Groups of hotels may be defined according to their proximity. Due to the complexity of graphically representing such a high number of ratings, the average points for each of the hotels in the dimensions analyzed were calculated in order to facilitate comprehension. From here on thirteen distinct clusters have been defined that were obtained by grouping those hotels under one cluster according to the two dimensions considered (see Table 3). 
Table 3

Ratings and Points for the dimensions of the types of hotel

\begin{tabular}{|c|c|c|c|c|}
\hline \multirow{2}{*}{ TYPES } & \multicolumn{2}{|c|}{ Number of hotel assessments } & \multicolumn{2}{c|}{$\begin{array}{c}\text { Average points } \\
\text { (scale of 1-10) }\end{array}$} \\
\cline { 2 - 5 } & $\mathbf{N}$ & $\mathbf{\%}$ & Dimensión 1 & Dimensión 2 \\
\hline TIPO 1 & 11,894 & 16.14 & & 1.1 \\
TIPO 2 & 1,967 & 2.67 & 8.9 & 6.9 \\
TIPO 3 & 5,127 & 6.96 & 2.7 & 4.2 \\
TIPO 4 & 2,954 & 4.01 & 6.8 & 1.2 \\
TIPO 5 & 9,525 & 12.92 & 2.5 & 6.8 \\
TIPO 6 & 1,904 & 2.58 & 1.1 & 8.9 \\
TIPO 7 & 6,021 & 8.17 & 7.4 & 2.6 \\
TIPO 8 & 9,332 & 12.66 & 7.8 & 3.7 \\
TIPO 9 & 3,161 & 4.29 & 8.9 & 7.0 \\
TIPO 10 & 11,854 & 16.08 & 6.1 & 9.0 \\
TIPO 11 & 1,357 & 1.84 & 4.5 & 5.5 \\
TIPO 12 & 2,383 & 3.23 & 1.9 & 3.3 \\
TIPO 13 & 6,219 & 8.44 & 5.3 & 3.2 \\
TOTAL & $\mathbf{7 3 , 6 9 8}$ & $\mathbf{1 0 0 . 0 0}$ & & \\
\hline
\end{tabular}

Source: Own elaboration.

Once hotels were assigned to each group, an analysis of the types of information associated with each cluster of hotels was carried out in order to identify possible common characteristics. This process allowed us to verify that the number of established groups met the criteria of substantiality and discrimination, confirming the existence of different types of hotels. The characterization of the thirteen groups was made from the information contained in the loyalty program database about the most common types of hotels associated with each of the thirteen groups. The common features associated with hotels assigned to each of the thirteen groups allow establishing distinct profiles (types of hotel). The label of each profile is representative of their characteristics. Table 4 contains the labels chosen for the thirteen categories and summarises the defining characteristics of each type. Also, each of the thirteen types is represented in Figure 3 according to the relative position of each one of them in regards to the two dimensions considered. Of these types, and according to the sampling distribution shown in Table 3, the most in-demand correspond to "Historic buildings converted to hotels" (16.14\%), "Charming rural hotels" (16.08\%), "Functional business hotels" (12.92) and "Beachfront hotels based on price" (12.66\%). 
Table 4

Description of types of hotel according to style / drivers

\begin{tabular}{|c|c|c|}
\hline TYPE & NAME & DESCRIPTION \\
\hline 1 & $\begin{array}{l}\text { Historic buil- } \\
\text { dings conver- } \\
\text { ted into hotels }\end{array}$ & $\begin{array}{l}\text { Ancient castles, palaces and manor houses converted into hotels, } \\
\text { high ratings for price, quality and service. Traditional decor with } \\
\text { regional influences. Mainly rural sites. }\end{array}$ \\
\hline 2 & $\begin{array}{l}\text { Large conven- } \\
\text { tional hotels }\end{array}$ & $\begin{array}{l}\text { Hotels located both in big cities and on the coast, specially-oriented } \\
\text { towards celebrations and corporate events. Large number of rooms } \\
\text { and characterized by including large meeting rooms. Average or } \\
\text { above average ratings for service and price. }\end{array}$ \\
\hline 3 & $\begin{array}{l}\text { Big coastal } \\
\text { hotels circa } 70 \mathrm{~s} \\
\text { and } 80 \mathrm{~s}\end{array}$ & $\begin{array}{l}\text { Hotels built along the Spanish coast in the } 70 \text { s and } 80 \text { s, coinciding } \\
\text { with the tourist boom. Usually located by the beach, which is their } \\
\text { main attraction. With architectural features strongly influenced by } \\
\text { the Bauhaus style, they have an average rating for price and low or } \\
\text { average for quality. }\end{array}$ \\
\hline 4 & $\begin{array}{l}\text { Large nine- } \\
\text { teenth century } \\
\text { hotels }\end{array}$ & $\begin{array}{l}\text { Reputable hotels with high rating for price, quality and service whose } \\
\text { emblematic architecture and elitist classical décor has become part of } \\
\text { the history of the major cities in which they are located. }\end{array}$ \\
\hline 5 & $\begin{array}{l}\text { Functional bu- } \\
\text { siness hotels }\end{array}$ & $\begin{array}{l}\text { Small and medium hotels located close to business centres and } \\
\text { transport hubs (airports, central high-speed train stations etc.). With } \\
\text { modern, unpretentious decor, average or below average price rating, } \\
\text { and competitive in terms of quality and service. They are characte- } \\
\text { rized by rooms which adjoin areas of work for executives, traders } \\
\text { or entrepreneurs, who constitute the principal client base of such } \\
\text { hotels. }\end{array}$ \\
\hline 6 & $\begin{array}{l}\text { Designer hotels } \\
\text { set in areas of } \\
\text { natural beauty }\end{array}$ & $\begin{array}{l}\text { Hotels with uniquely distinct components in terms of architecture } \\
\text { and environmental setting. Located outside of big cities, they gain } \\
\text { their unique value through their location in areas of natural beauty } \\
\text { such as along coastlines or in the mountains. The minimalist and/ } \\
\text { or avant-garde surroundings are especially well-considered. High } \\
\text { ratings for price and quality. }\end{array}$ \\
\hline 7 & $\begin{array}{c}\begin{array}{c}\text { Rural ho- } \\
\text { tels oriented } \\
\text { towards leisure }\end{array} \\
\text { Activities } \\
\end{array}$ & $\begin{array}{l}\text { Small hotels geared towards sporting activities and/or relaxation, } \\
\text { both outdoors and indoors: horse riding routes, gastronomic tours, } \\
\text { scenic walks, etc. Local indigenous décor combined with modern } \\
\text { service. Average rating for price, quality and service. }\end{array}$ \\
\hline 8 & $\begin{array}{c}\text { Beachfront } \\
\text { hotels based on } \\
\text { price }\end{array}$ & $\begin{array}{l}\text { Hotels belonging to large national and multinational hotel chains } \\
\text { normally associated with tour operators. Strong Internet presence } \\
\text { (either through their own channels or through third-party media). } \\
\text { Low to average ratings for quality, service and price. They tend not } \\
\text { to have a well-defined style of decoration or architecture and are } \\
\text { characterized by their uniformity. }\end{array}$ \\
\hline 9 & $\begin{array}{c}\text { Golf, ski and } \\
\text { spa hotels, }\end{array}$ & $\begin{array}{l}\text { Hotels with high rating for price and quality, but with uneven servi- } \\
\text { ces. Built next to areas for recreational sports (especially golf cour- } \\
\text { ses and ski slopes), such hotels combine modern surroundings with } \\
\text { facilities in which sporting activities can be practiced by guests, and } \\
\text { include services for fitness, spa treatments and heated swimming } \\
\text { pools for guests to enjoy within the hotel grounds. }\end{array}$ \\
\hline
\end{tabular}




\begin{tabular}{ccl}
\hline $\mathbf{1 0}$ & $\begin{array}{c}\text { Charming } \\
\text { rural hotels }\end{array}$ & $\begin{array}{l}\text { A recently introduced type of hotel aimed at relaxing weekends and } \\
\text { short breaks. Unique selling points include a very personalized and } \\
\text { intimate service. They tend to be small to medium sized and, unlike } \\
\text { rural hotels oriented towards leisure activities, possess intimate and } \\
\text { internal drivers such as gyms, spas and saunas that make an enjoya- } \\
\text { ble stay possible without the need to go outside. Medium-high price } \\
\text { rating, and average for service and quality. }\end{array}$ \\
\hline $\mathbf{1 1}$ & $\begin{array}{c}\text { Urban, desig- } \\
\text { ner hotels }\end{array}$ & $\begin{array}{l}\text { Urban, avant-guarde and exclusive, such hotels are located in large } \\
\text { cities and incorporate works of art and pieces from renowned de- } \\
\text { signers as part of their decor. High rating for price and quality. }\end{array}$ \\
\hline & Unclassifiable & $\begin{array}{l}\text { Hotels that, due to the ambiguous perceptions of guests regarding } \\
\text { their style and décor or the intermediate value of their internal or } \\
\text { external drivers (very different from other hotels), it has not been } \\
\text { possible to include in any group. }\end{array}$ \\
\hline $\mathbf{1 3}$ & Small city \\
hotels & $\begin{array}{l}\text { Family-run hotels with between ten and thirty rooms situated in the } \\
\text { centre of large cities (e.g., Madrid, Barcelona, Valencia, Sevilla). } \\
\text { Average ratings for price, quality and service. Décor and style are } \\
\text { not well-defined, with emphasis, instead, being placed on the service } \\
\text { and central location. }\end{array}$ \\
\hline
\end{tabular}

Source: Own elaboration.

Figure 3

Perceptual map of hotels according to positioning for style / drivers

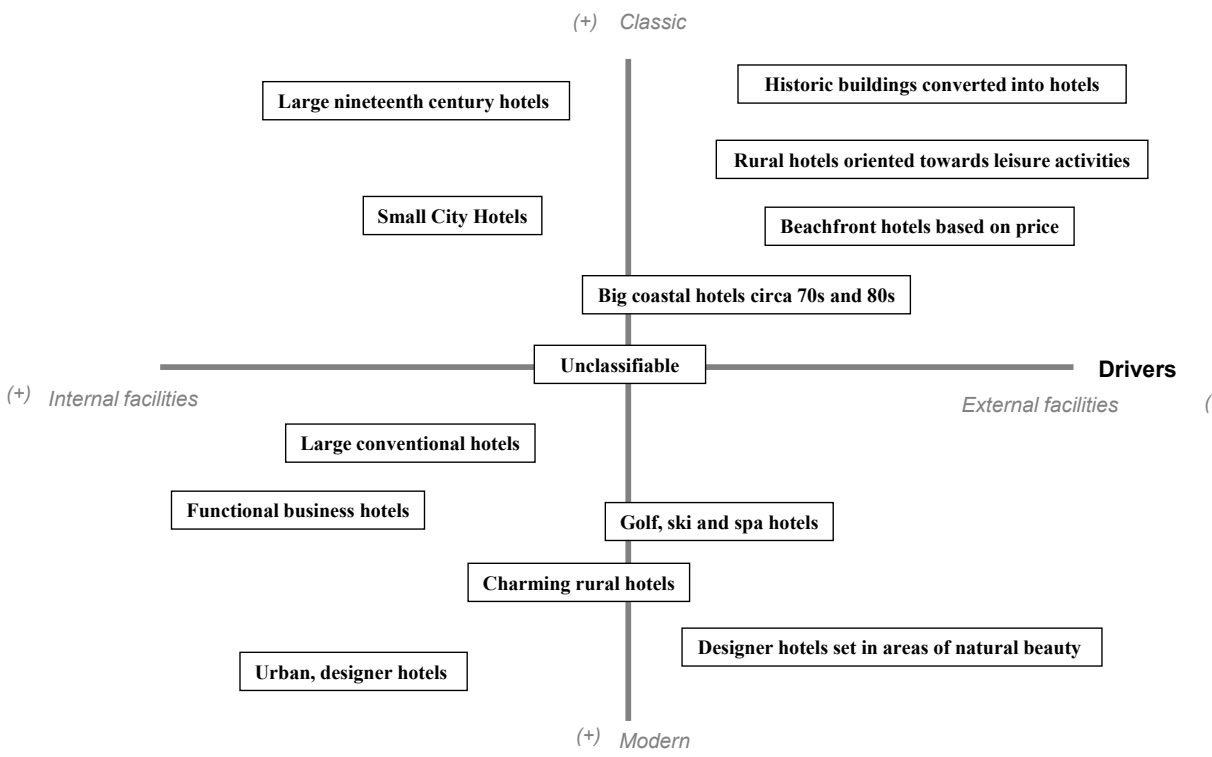

Source: Own elaboration. 
With this study it has been possible to propose a classification for the hotels in the Spanish market from the perspective of demand - that is, from the assessments made by hotel guests - and determine the basis underlying their selection. This new system of classification has a greater number of categories than those set out in official classifications. These results show that a classification that takes into account the style of the hotel and the relative importance placed on facilities versus its location in a particular environment, can be used to classify the current range of hotels in Spain from the perspective of demand.

Having described the characteristics of each of these types of hotel, it turns out to be advantageous for managers to determine into which category guests place their establishments. The representation of the thirteen types on a positioning map (Figure 3 ) helps to determine, in a clear and concise manner, how customers perceive the hotel market as a whole, and identify from the characteristics of a particular hotel its place on the positioning map and direct competition in the local environment (types of hotel nearby) according to the perceptions of customers, to this type of establishment. In order that this classification has practical value for hotel management, it is necessary to know the customer profile for each type of establishment. Table 5 shows the influence of the main sociodemographic characteristics and behavior of respondents as reflected by their choice of type using a chi-square test. In this analysis, the category of "unclassified" is not considered. As is clear from the results, all the variables analyzed influence hotel selection, the most relevant being number of years in the program and points used.

However, given the need to know the user profile of each type and by reference to the percentages in Table 5, the weights of the different variables analysed were calculated for each type of hotel in order to determine which variables may be used as criteria or bases of segmentation for each type of hotel. 


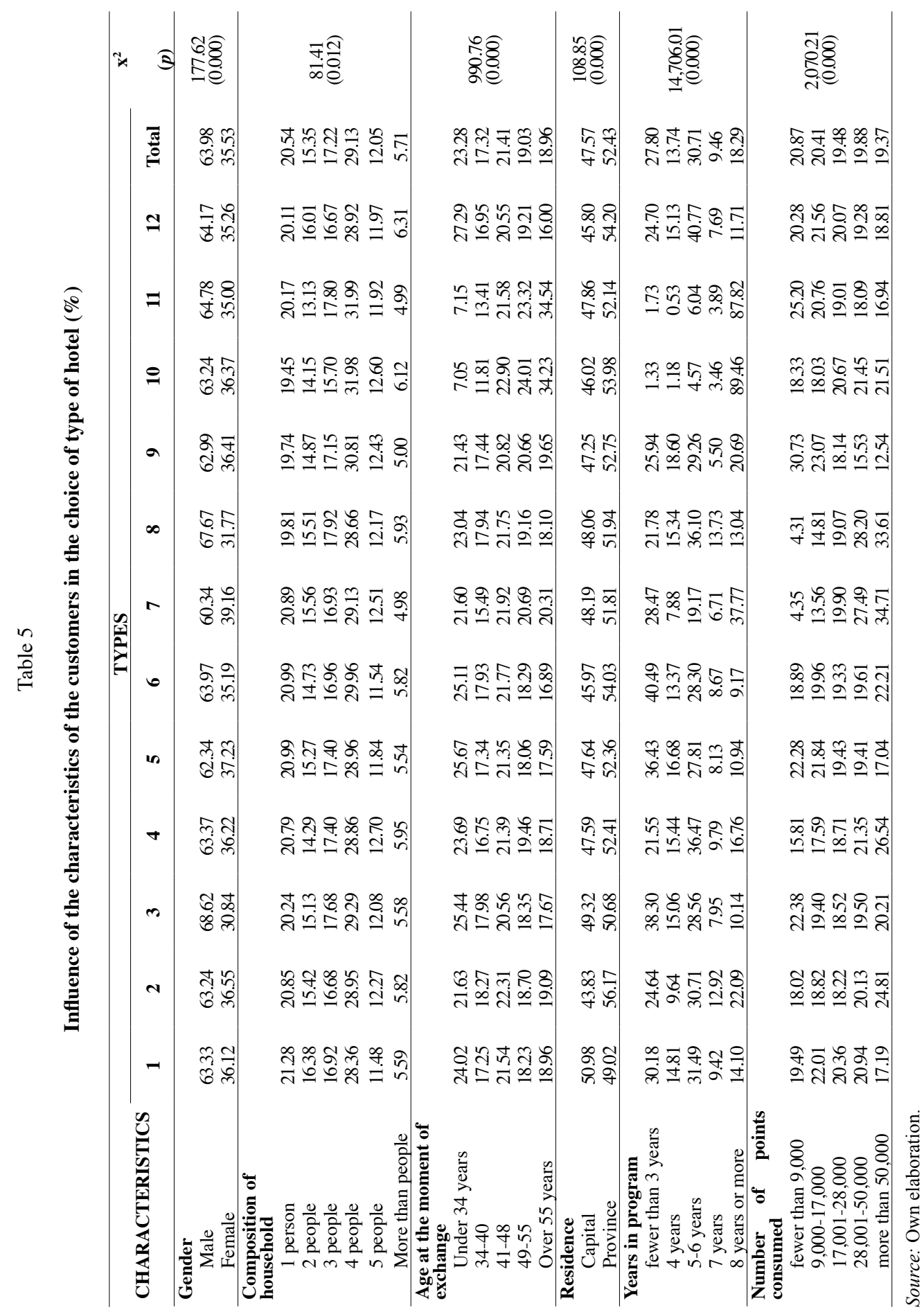




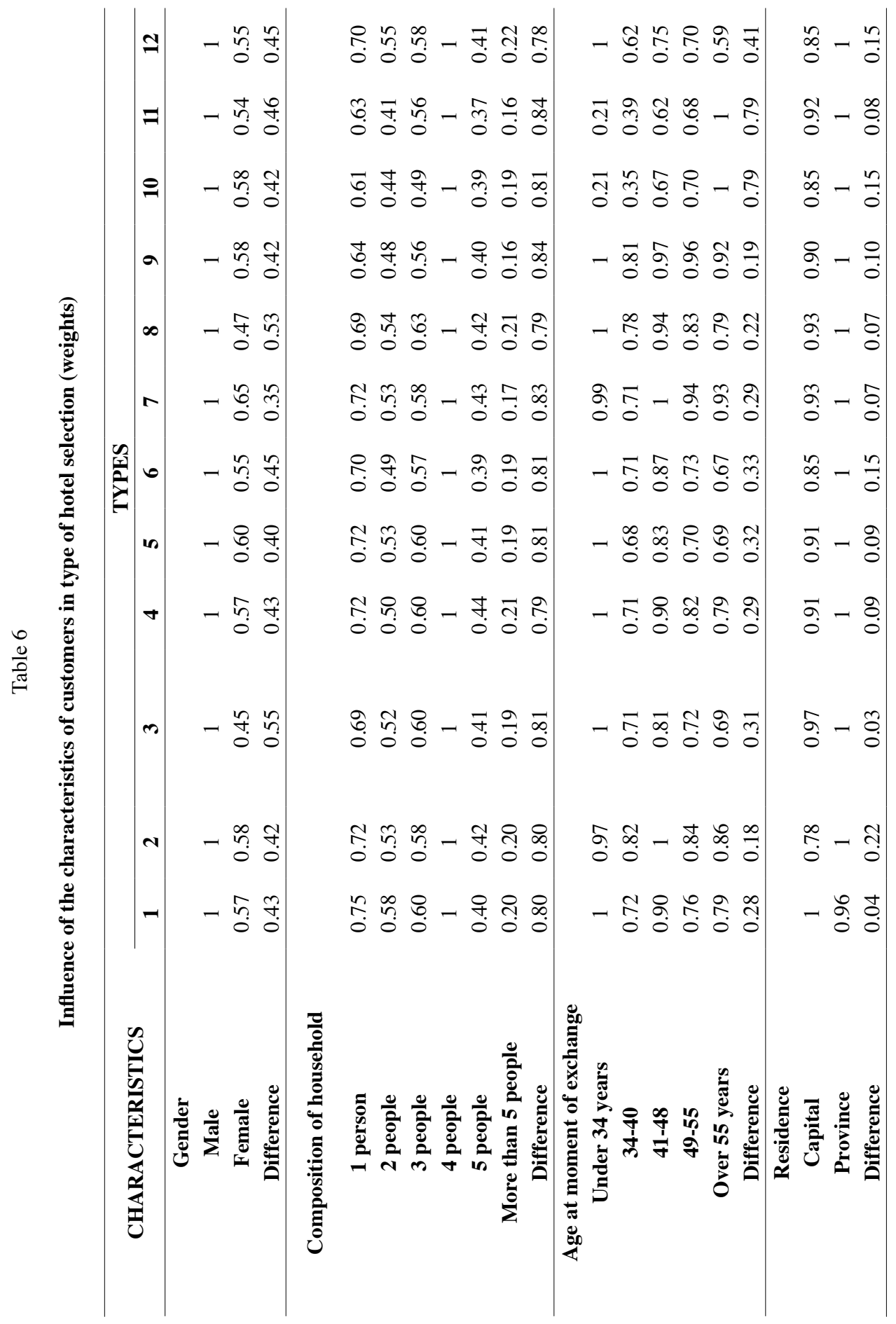




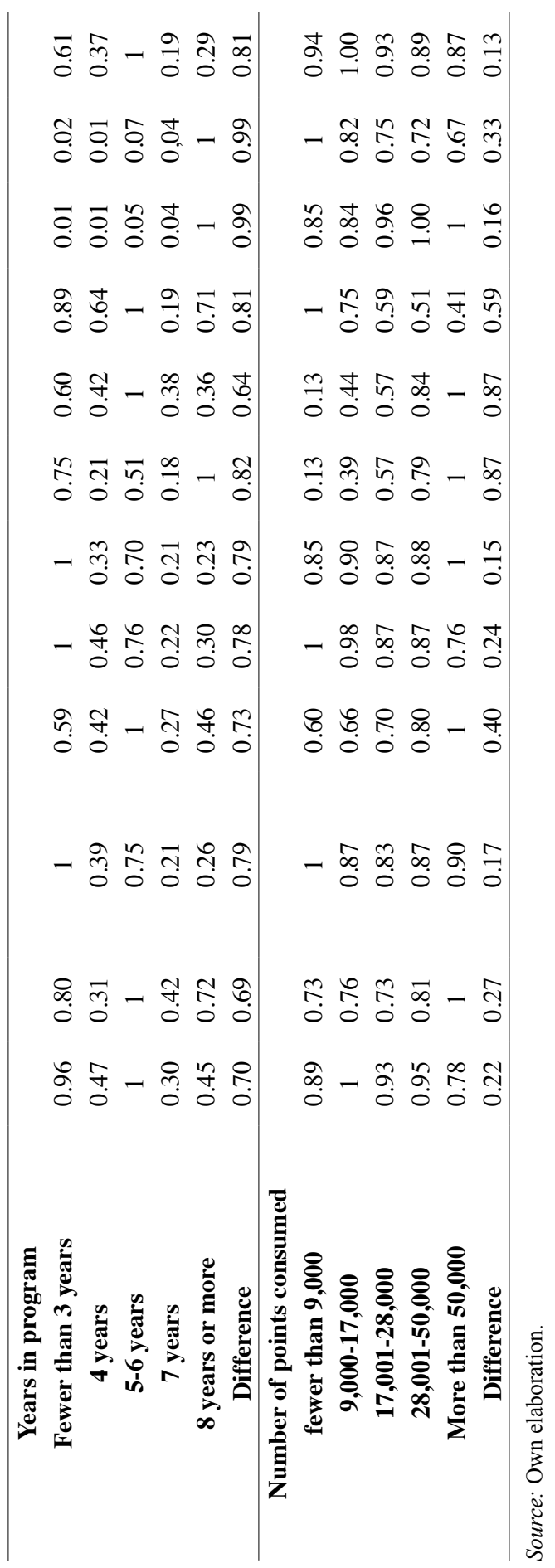


As shown in Table 6, the variables used to characterize the different customer profiles of the twelve types of hotel have different levels of influence, allowing managers to make decisions relative to the choices of a particular target audience. First, we note that the variable 'residence' cannot be considered as a good basis of segmentation, because the weight of customers resident in either capital cities or provinces is very similar for all twelve types, hence the differences are minimal ranging between 0.03 and 0.22 .

As regards the variable 'gender', it cannot be said that its importance as the basis of segmentation differs in relation to the type of establishment, although it is noteworthy that, in all cases, men tend to redeem their points most often.

The variable 'composition of the household can be regarded as a good criterion for segmentation of customers as the differences in all types of hotels exceed or are close to 0.8. However, it is not a criterion that permits discrimination between types. As in all cases, it is best to direct marketing activities towards households formed of between 1 and 4 persons, it being, at the same time, only possible to target single-person households or those with 4 members, since these are the two most common states.

The variable 'age' may only be considered a good criterion for segmentation for types 10 (Charming rural hotel) and 11 (Urban designer hotel), which shows that the older segments of the population are the most demanding of this type establishment. For all other types this is not a good criterion to the extent that the remaining types are in demand by all age levels in very similar percentages.

As is clear from the data collected in this Table, hotels can also use the information derived from the database of the loyalty program to better manage their customer relationships. Thus, the age of the clients in the program is a relevant consideration when defining the user profile of each hotel, as it affects the selection of different types of hotel. For example, the oldest customers in the program (8 or more years) opt for types 7 (Rural hotels oriented towards leisure activities), 10 (Charming rural hotels) and 11 (Urban designer hotels); while younger customers tend to opt for types 3 (Big coastal hotels circa 70s and 80s), 5 (Functional business hotels) and 6 (Designer hotels set in areas of natural beauty). Similarly, the volume of accumulated loyalty program reward points can determine whether a particular type of establishment is selected. This is a valid criterion mainly for types 7 (Rural hotels oriented towards leisure activities) and 8 (Beachfront hotels based on price), in which customers with a high volume of points (more than 50,000 ) are opting for both categories.

\section{CONCLUSIONS AND RECOMMENDATIONS}

This work contributes by expanding the research into the role of classification for the accommodation on offer from the perspective of demand, noting the need for and benefits of its implementation.

From the field of academia, research has confirmed the importance of loyalty programs in integrating a large volume of information that can serve hotels in knowing their customers better and adapting their marketing strategies accordingly. Any hotel that joins a multi-sponsor loyalty program can benefit by obtaining the information necessary to make strategic and tactical decisions on how to formulate proposals of value targeted at specific groups of customers. 
In this context, one hypothesis that has guided much of the work is associated with the problems arising from the existence of hotel categories which are based on the official government system of classification, and their possible interference with business relationships and the market. The results support the notion that guests are better able to group hotels into a greater number of categories and in respect to a greater number of the features that are required for stars to be awarded in official classifications. Therefore, since the official classification of hotel categories is governed, in fact, by measuring a limited number of features and facilities - principally those of an objective or tangible nature - essential features which are liable to be assessed by guests are overlooked. From this perspective, the current system of classification for hotels constitutes a barrier to market orientation, because it is not fixed in terms of perception and assessment of demand. Considering the need for diversity of supply, the current classification does not allow for the configuration of added value by taking into account the range of features identified by guests.

The results of this research have different implications for the hotel business sector. In respect to the primary objective of this work regarding the proposal of a new system of classification for hotels, the implementation of this new system of hotel classification from the perspective of demand can form part of a differentiation strategy that is not conditioned by legal restrictions. This fact should be reflected in the communication strategies employed with customers and regarded as a both challenge and an opportunity for businesses competing in the market. From the point of view of marketing and communications for hotels, managers must make an effort to communicate the various features associated with each of the thirteen groups - in opposition to the interference presented by communications based only on official categories - with criteria set out by demand, as is proposed in the classification provided. The provided characterization of hotel guests can meet the specialized needs of different types of establishment in specific segments.

In a very fragmented sector - such as the hotel sector - with a large number of small businesses controlling limited resources, this system of classification may be found to be an accessible and valuable tool for communication with customers. The customer knowledge provided by the proposed system of classification allows small establishments to gain operative shares in the frequent micromarketing of chains with large resources. Finally, it should be noted that the diversity of established typologies and the descriptors used in the proposed system of classification makes it very representative of the diversity on offer and a tool that will allow customers to refine their decision-making process. In this sense, it offers customers an additional source of information which can be used to complement that provided by the official classifications. With this system of classification, customers can identify establishments more in line with their personal preferences. Likewise, it is particularly interesting for those establishments that cater to international tourism, given the limitations that can be assumed in the customer's decision-making process due to the heterogeneous criteria for granting administrative categories in various countries.

It is noted, as a limitation of this work, that the use of a questionnaire involves some degree of subjectivity in relation to the assessments used in the classification, which, however, is accurate to assume from the perspective of demand requiring a classification proposal. Moreover, although the proposed system of classification has been obtained in the context of a loyalty program associated with millions of people and a wide representation of sociodemographic profiles, the results proposed can only be considered representative 
of those associated with a loyalty program and hotels that currently form part of a multisponsor structure. As a future line of research, we intend to validate the proposed system of classification using customers not belonging to a loyalty program.

\section{REFERENCES}

Aguiló, E. and Alegre J., 2004. La madurez de los destinos turísticos de sol y playa. El caso de las Islas Baleares. Papeles de la Economía Española, 102, 250-270.

Albert, I., 1999. Gestión, productos y servicios de las agencias de viajes. Madrid: Ramón Areces.

Allaway A., Richard M., Gooner, R., Berkowitz, D. and Davis, L., 2006. Deriving and exploring behaviour segments within a retail loyalty card program. European Journal of Marketing, 40 (11/12), 1317-1339.

Byrom, J.2001., The role of loyalty card data within local marketing iniciatives. International Journal of Retail \& Distribution Management, 29 (6/7), 333-342.

Callan, R.J. and Kyndt, G., 2001. Business travellers' perception of service quality: A prefactory study of two European city centre hotels. International Journal of Tourism Research, 3 (4), 313-323.

Campo, S. and Yague, M.J., 2011. Los precios de referencia en la evaluación online del servicio hotelero. Estudios de Economía aplicada, 29 (3), 825-844.

Carrilero, A., Llopis, M.P. and Guijarro, M., 2012. Cómo mejorar el valor percibido del cliente en el hotel. En Actas de XXIV Congreso Nacional de Marketing. AEMARK. Palma de Mallorca: Esic Editorial.

Caso Fernández-Pacheco, L., 2012. Las certificaciones de calidad en las empresas turísticas: antecedentes y consecuentes. Tesis, (Dr). Universidad de Oviedo.

Caso Fernández-Pacheco, L. and Iglesias Argüelles, V., 2013. Las certificaciones de calidad en cadenas hoteleras: antecedentes de su implantación. En: Actas de XXV Congreso Nacional de Marketing. AEMARK. Barcelona: Esic Editorial.

Claver Cortés, E., Pereira Moliner, J. and Molina Azorín, J.F., 2007. Impacto del tamaño, el tipo de gestión y la categoría sobre el desempeño de los hoteles españoles. Cuadernos de Turismo, 19, 27-45.

Cortiñas, M., Elorz, M. and Múgica, J. M., 2005. Loyalty cards: Are retailers ignoring noncard-holder behaviour? European Retail Digest, 45, 18-20.

De Querol Aragón, N., 2010. Preferencias del turista en España. Un estudio en función de la categoría del establecimiento hotelero elegido: 1983-2008. Estudios Turísticos, 183, 43-74.

Dekay, F., Toh, R.S. and Raven, P., 2009. Loyalty programs: Airlines outdo hotels. Cornell Hospitality Quarterly, 50 (3), 371-382.

Devesa, M., Laguna, M. and Palacios, A., 2010. Motivación, satisfacción y lealtad en el turismo: El caso de un destino de interior. Revista Electrónica de Motivación y Emoción, 13 (35-36), 170.

Füller, J. and Matzler, K., 2008. Customer delight and market segmentation: An application of the three-factor theory of customer satisfaction on life style groups. Tourism Management, 29 (1), 116-126.

Guillet, B. and Law, R., 2010. Analyzing hotel star ratings on third-party distribution websites. International Journal of Contemporary Hospitality Management, 22 (6), 797-813. 
Hair, J.F., Anderson, R.E., Tathan, R.L. and Black, W.C., 2007. Multivariate data analysis. New Jersey: Pearson/Prentice Hall.

Hosteltur and Deloitte 2012. I Encuesta Hosteltur \& Deloitte Turismo 2012. Hábitos y tendencias de los viajeros según los agentes de viajes. Hosteltur, 212, 8-34.

Ibrahim, E. and Gill, J., 2005. A positioning strategy for a tourist destination, based on analysis of customers' perceptions and satisfactions. Marketing Intelligence \& Planning, 23 (2), 172-188.

Kandampully, J. and Suhartanto, D., 2013. The role of customer satisfaction and image in gaining customer loyalty in the hotel industry. Journal of Hospitality \& Leisure Marketing, 10 (1-2), 3-25.

Kim, B., Shi, M. and Srinivasan, K., 2001. Rewards programs and tacit collusion. Marketing Science, 20 (2), 99-120.

Kopalle, P. K. and Neslin, S. A., 2003. The economic viability of frequency reward programs in a strategic competitive environment. Review on Marketing Science, 1 (1), 1-39.

Lara, P. and Martínez, J.A., 2002. Comercio electrónico: la fidelización del usuario. El Profesional de la Información, 11 (6), 408-420.

Lo, A.S., Stalcup, L.D. and Lee, A., 2010. Customer relationship management for hotels in Hong Kong. International Journal of Contemporary Hospitality Management, 22 (2), 139-159.

Long, M and Schiffman, L., 2000. Consumption values and relationships: segmenting the market for frequency programs. Journal of Consumer Marketing, 17 (3), 214-232.

López, M.C. and Serrano, A.M., 2004. Is the hotel classification system a good indicator of hotel quality? Tourism Management, 25, 771-775.

Lovelock, C.H., 1983. Classifying services to gain strategic marketing insights. Journal of Marketing, 47 (3), 9-20.

Marmorstein, H., Rossomme, J. and Sarel, D., 2003. Unleashing the power of yield management in the internet era: Opportunities and challenges. California Management Review, 45 (3), 147-167.

Marques, C., Reis, E. and Menezes, J., 2010. Profiling the segments of visitors to Portuguese protected areas. Journal of Sustainable Tourism, 18 (8), 971-976.

Mauri, C., 2003. Card loyalty: a new emerging issue in grocery retailing. Journal of Retailing and Consumer Services, 10 (1), 13-25.

Mazanec, J., 1995. Positioning analysis with self-organizing maps: An exploratory study on luxury hotels. Cornell Hotel and Restaurant Administration Quarterly, 36 (6), 8095.

Meyer-Waarden, L. and Benavent, C., 2003. Les cartes de fidélité comme outils de segmentation et de ciblage. Le cas dúne enseigne de distribution. Decisions Marketing, 32 (Oct.-Dec.), 19-30.

Michels, N. and Bowen, D., 2004. The relevance of retail loyalty strategy and practice for leisure/tourism. Journal of Vacation Marketing, 11 (1), 5-19.

Montoro, F.J., Luque, T. and Cañadas, P., 2006. Improving attitudes toward brands with environmental associations: an experimental approach. Journal of Consumer Marketing, 25 (1), 26-33.

Muhr, T., 2004. User's Manual for ATLAS.Ti 5.0. Berlin: Scientific Software Development. 
Noone, B.M. and McGuire, K.A., 2013. Pricing in a social world: The influence of nonprice information on hotel choice. Journal of Revenue and Pricing Management, 12, 385-401.

Park, D.B. and Yoon, Y.S., 2009. Segmentation by motivation in rural tourism: A Korean case study. Tourism Management, 30 (1), 99-108.

Palmer, A., Mcmahon-Beattie, U. and Beggs, R., 2000. A structural analysis of hotel sector loyalty programmes. International Journal of Contemporary Hospitality Management, 12 (1), 54-60.

Ponzoa, J.M. and Reinares, P., 2010. Los programas de fidelización como plataforma de venta directa: clasificación de los titulares según redención de billete aéreos. Cuadernos de gestión, 10 (extra 1), 197-213.

Reinares, E. and Esteban, A., 1996. Comunicación e imagen en los servicios hoteleros. Madrid, Spain: Ministerio de Economía y Hacienda. Instituto de Estudios Turísticos.

Reinares, P., Reinares, E. and Mercado, C., 2010. Gestión de la heterogeneidad de los consumidores mediante programas de fidelización. Revista Europea de Dirección y Economía de la Empresa, 19 (3), 143 -160.

Rowley, J., 2005. Building brand webs: Customer relationship management through the Tesco Clubcard loyalty écheme. International Journal of Retail \& Distribution Management, 33 (3), 194-206.

Sánchez-Ollero, J.L., García-Pozo, A. and Marchante-Mera, A.J., 2014. Análisis de la incidencia de las certificaciones de calidad sobre la productividad de los hoteles en Andalucía. Universia Business Review, 44, 88-103

Varela, J.V., Prat, R., Voces, C. and Rial, A., 2006. Una nueva escala para la evaluación de la calidad de los servicios de hostelería. Psicotema, 18 (1), 135-142.

Yavas, U. and Babakus, E., 2003. What Do Guests Look for in a Hotel? A multi-attribute approach. Services Marketing Quarterly, 25 (2), 1-9.

Ziliani, C. and Bellini S., 2004. From loyalty cards to micro-marketing strategies: where is Europe's retail industry heading? Journal of Targeting, 12 (3), 281-289. 